\title{
Epistemological surveillance and the Bourdieusian approach in the accounting field
}

\author{
MARA VOGT ${ }^{1}$ \\ MARCIA ZANIEVICZ DA SILVA ${ }^{1}$ \\ IONE RIBEIRO VALLE ${ }^{2}$ \\ ${ }^{1}$ Universidade Regional de Blumenau (FurB) / Postgraduate Program in Accounting Sciences, Blumenau - SC, Brazil \\ 2 Universidade Federal de Santa Catarina (UFSC) / Graduate Program in Education, Florianópolis - SC, Brazil
}

\begin{abstract}
A variety of themes have increasingly been studied in accounting; some of them are quite extravagant, others less. In any case, it is necessary to dedicate attention and develop expertise on these themes to produce new knowledge with clarity and coherence. This is what French sociologist Pierre Bourdieu calls, in general, epistemological surveillance. Notably, Bourdieu's theory, especially that of the field, capital, and habitus, has been used in the most diverse areas of knowledge and, in recent years, with some prominence in the accounting area, even if in a secondary way, as a conceptual complement. This theoretical essay analyzes the coherence in using the Bourdieusian approach in the accounting field through epistemological surveillance. It also recommends new possibilities for studies based on previous literature. The analysis of the work of this author and some of his followers demonstrates that some studies lack coherence, a phenomenon Bourdieu (2001) calls allodoxia.
\end{abstract}

Keywords: Accounting. Bourdieu. Epistemological Surveillance. Axiology. Allodoxia.

\section{“Comendo pelas beiradas": vigilância epistemológica e a abordagem Bourdieusiana no campo contábil}

\section{Resumo}

Têm aumentado os estudos com temáticas totalmente diferenciadas na área contábil, alguns mais extravagantes e outros mais inofensivos. Contudo, em ambos os casos, é necessário dar atenção e domínio ao assunto para produzir novos conhecimentos com clareza e coerência. É isso que o sociólogo francês Pierre Bourdieu denomina, em linhas gerais, de vigilância epistemológica. Notadamente a teoria de Bourdieu, em especial a do campo, capital e habitus, tem sido utilizada nas mais diversas áreas do conhecimento e, nos últimos anos, com alguma preeminência na área contábil, mesmo que de modo secundário, como complemento conceitual. Por meio da vigilância epistemológica, recomendada por Bourdieu, este ensaio teórico teve por objetivo analisar a coerência na utilização da abordagem bourdieusiana no campo contábil, bem como indicar novas possibilidades de estudos, tendo como ponto de partida algumas pesquisas já realizadas. Com base na obra desse autor e de alguns de seus seguidores, foi possível observar falta de coerência em algumas pesquisas, ou seja, aquilo que Bourdieu (2001) nominou de allodoxia.

Palavras-chave: Contabilidade. Bourdieu. Vigilância Epistemológica. Axiologia. Allodoxia.

\section{“Comiendo por los bordes": vigilancia epistemológica y enfoque Bourdieusiano en el campo contable}

\section{Resumen}

Los estudios con temas totalmente diferentes en el área de contabilidad han aumentado, algunos más extravagantes y otros más inofensivos. Sin embargo, en ambos casos, es necesario darle atención y dominio al tema para producir nuevos conocimientos con claridad y coherencia. Esto es lo que el sociólogo francés Pierre Bourdieu llama, en general, vigilancia epistemológica. Cabe destacar que la teoría de Bourdieu, especialmente la del campo, el capital y el habitus, se ha utilizado en las más diversas áreas del conocimiento y, en los últimos años, con cierta prominencia en el área contable, aunque sea de manera secundaria, como un complemento conceptual. A través de la vigilancia epistemológica, recomendada por Bourdieu, este ensayo teórico tuvo como objetivo analizar la coherencia en el uso del enfoque bourdieusiano en el campo de la contabilidad, así como indicar nuevas posibilidades de estudios, tomando como punto de partida algunas investigaciones ya realizadas. Con base en el trabajo de este autor y algunos de sus seguidores, fue posible observar una falta de coherencia en algunos estudios, es decir, lo que Bourdieu (2001) denominó allodoxia.

Palabras clave: Contabilidad. Bourdieu. Vigilancia epistemológica. Axiología. Allodoxia. 


\section{INTRODUCTION}

Pierre Félix Bourdieu was a sociologist recognized for his discussions relevant to Social Science, which involve aspects such as power relations and the triad that helps to explain these relations: field, habitus, and capital. In addition, he was a researcher who defended the axiology of knowledge, that is, everything that refers to a concept of value and that deserves research in several contexts (Bourdieu, Chamboredon \& Passeron, 2015) and in several areas, for example: Education, Economy, Administration, History, Design, Marketing, Fashion, Law and Accounting.

As a researcher, besides the axiology of knowledge, Bourdieu emphasized the importance of epistemological surveillance, which refers to the fact that data, analysis, choices and theory are "watched" in relation to their consistency with the study proposal (Bourdieu et al., 2015). The authors make it clear that if there is no coherence in the use of concepts (axiology), we will have allodoxia: doxas (truths) biased, i.e., truths appropriate in the wrong way (Bourdieu et al., 2015). This allodoxia is produced, for example, by the distance that separates the intellectual fields all over the world, being necessary, in global scope, to recognize the differences from one context to another (Bourdieu, 1997b). Thus, we realize the importance that Bourdieu attaches to coherence in the use of concepts and theories, regardless of the researcher, object or area studied.

In view of the above and considering the relevance of Bourdieu's sociological work, this theoretical essay aims to analyze the coherence in the use of the Bourdieu approach in the accounting field, as well as to indicate new possibilities of studies, going beyond what has already been explored in the area.

Throughout Bourdieu's work, the author explains the need for epistemological surveillance, as we have already stated. Bourdieu (2001) shows that research is a discourse to which the agent is exposed and for which he takes risks. Moreover, the author stresses that sometimes researchers ignore important methodological foundations. However, for Bourdieu (2001), research is something that deserves seriousness (rigor), difficult to be based on only one methodology, since there are several that can be used, being necessary to take the context into consideration for each situation.

Before exposing how studies in the accounting area have appropriated Bourdieu's theory, it is important to pay attention to the understanding of what is power for this author and where this concept emerged in his work. The concept of power is complex and, according to Bourdieu (1989), is directly related to the domination and reproduction of the status quo. Hey (2017, p. 293) observes that, to be effective, power must have and present itself in "[...] a form of ignorance and recognition, rooted in the body of structures of domination, social and historically forged, acting to generate a social order. Such an order is inscribed in the relations of force, being taken as the natural order of things".

For Bourdieu $(1989,1991)$, power relations tend to reproduce themselves in the form of symbolic power, that is, of invisible power that can only be exercised with the complicity of the dominated in relation to the dominant. However, power relations should not be seen exclusively as something negative and repressive. For Bourdieu, power relations are articulating, enabling and inventive. In this context, it is possible to formulate two questions. Why study Bourdieu in accounting? How does Bourdieu's theory contribute to accounting research? Considering the breadth of this theory and its relevance, Bryer (2011) stresses that it is possible to understand the importance of looking at the studies developed in the accounting area, since accounting is essential to all organizations. It is also relevant to highlight that, based on the Bourdieusian approach; accounting reinforces the power relations established in the field, mainly by allowing agents to articulate certain issues, needs and personal desires (Bryer, 2011).

Applying Bourdieu's concepts to explain the absence of studies with interpretative and critical approaches in accounting, Homero (2017) concluded that Brazilian accounting research, characteristically positivist and of little diversity, is little developed in those approaches; in part, due to the low autonomy of the academic field in relation to the professional field. The author warns about the need to expand the thematic, methodological, and epistemological variety of accounting research, as well as the approximation between accounting theory and practice.

In view of the above-mentioned context and taking into consideration epistemological surveillance, analyzing the coherence of use of concepts and authors is fundamental when it comes to scientific research. Based on a review of the literature in the Brazilian context, there are few studies in the accounting area that adopt Bourdieu's theory as a basis. This constitutes 
a gap to be explored and, with it, a contribution, especially with the purpose of offering a reflection on the axiology of Bourdieu's knowledge.

The methodology used was of an exploratory and analytical-descriptive nature. Data obtained from bibliographic examinations were analyzed in a qualitative way. For Hoskin and Macve (2000) we need to go back to the past to discover and analyze new evidence and patterns. In the case of this study, we go back to the past in the search for previous studies, to identify what has already been done and, thus, evolve with future studies. At the same time, identify the strengths and weaknesses of studies already conducted based on coherence, analyzing them through epistemological surveillance.

To this end, the research describes studies published in Brazil, which rely on Bourdieu to clarify or explain issues related to accounting topics. To select the studies, a search was carried out at the Portal da Capes (in July 2018) using the term "Bourdieu", intercalating it with the other keywords: "accounting", "accounting", "accounting". With the search filter established, 126 articles were initially retrieved. Excluding duplicity and false recoveries, 82 articles was obtained in which, after reading the title and abstract, aspects related to the Bourdieu approach were identified, especially in relation to its triad, which involves the field, habitus and capital, resulting in a total of 10 studies whose proposals were coherent with the objective of this research.

The theoretical essays make it possible to expand interdisciplinarity, promoting the construction and evolution of knowledge, without having a pattern or model, demanding more efforts from researchers to achieve the proposed objective (Meneghetti, 2011). Through these studies it is possible to identify new elements, however, requires further reflection to think and rethink phenomena (Meneghetti, 2011).

This study is organized in four sessions; besides the introduction, we have the second session dedicated to the description of some of the concepts present in Bourdieu's work. Following, we present the studies recovered in the accounting area that use the author's studies, which allowed to compose a cloud of words, generated with the most frequent words in the abstracts and key words of the analyzed articles, to finally present reflections on this use of Bourdieu's work in accounting research.

\section{BOURDIEU'S CONCEPTUAL TRIAD}

Bourdieu has developed, over the years, several concepts to explain people's behavior with reference to their relationships. For that, he proposed a triad formed by the countryside, habitus, and capital. For the author, in the field, the construction of the object that will command or guide the research practices takes place. This field is the space of pressure, competition, and disputes among agents (Bourdieu, 2005). It is relevant to point out that disputes between and among fields occur with the purpose of conquering or redefining one or more capitals, and may include economic, educational, cultural, social, political, symbolic capital, among others (Lahire, 2017). Thus, one must initially understand the field to then understand how power is given in this context and how habitus influences such relations, not least because power relations permeate human relations (Bourdieu, 1989, 1991).

For Bourdieu (1989), habitus understands the previous experiences that the individual carries with him, the system of dispositions, rules, beliefs and stories that influence him/her to seek the legitimization of capital(s), according to the desires, objectives, demands and/or pressures suffered by each one. For Setton (2002), habitus is a system engendered in the past and oriented to actions in the present, which may be conscious or, in most cases, unconscious. However, this habitus cannot be considered immutable, since the system of arrangements is being 'fed' continuously, being open to new experiences.

To complete the triad, we have the concept of capital. The theory proposed by Bourdieu is based on the assumption that in a field there is always something at stake and, in this game, there is the search for obtaining or strengthening some capital(s), which facilitates the conquest of certain positions of power and prestige. According to Bourdieu (1989), the capital is a resource that enables the conquest of power, besides, the amount of capital that an agent possesses is determinant for his position in the field, which may be of greater or lesser prestige. He also makes it clear that those who have capital(s) manage to dominate and reproduce the power. 
According to Bourdieu and Wacquant (1992), a capital only exists and is strengthened if there is a field, since the capital(s) confers a power inside the field. Munro (1993) stresses that the positions of social actors in the countryside are determined by the volume and composition of the capital they possess, and the struggles in countryside occur to accumulate several forms of capital. For Baxter and Chua (2008), the different positions in a camp are established according to the access to and legitimization of the forms of capital(s).

In relation to capital, there is economic, educational, cultural, social, political, and symbolic capital, among others that are considered forms of power (Bourdieu, 1989). As economic capital, Bourdieu (1991) considers material wealth in the form of remuneration. Lebaron (2017) complements that it can also be patrimonial, such as: real estate, automobiles, among others educational capital refers to knowledge, skills, educational or technical qualifications (Bourdieu, 1998), diplomas, writing and reading (Nogueira, 2017), among others. The cultural capital is composed of religion, art, science, philosophy, travel, among other forms (Bourdieu, 2004b; Lebaron, 2017). On the other hand, the capital concerns a durable network of personal relationships, being directly related to the other forms of capital (Bourdieu, 1998). Political capital is obtained in the form of votes and reflected in representativeness, as well as through positions, which goes back to trust and obedience (Bourdieu, 1991).

Symbolic capital - very present in the accounting context - is considered the value attributed to an individual by society, which recognizes and values him/her (Lebaron, 2017). For Bourdieu (1991), this is a capital that comes from prestige and recognition, from honor and reputation, being represented, according to Bourdieu (1998), through tributes. The symbolic capital is the result of the accumulation and combination of other capital in each field (Bourdieu, 1998).

Lebaron (2017, p. 103, emphasis added) emphasizes that the capital sustained by Bourdieu "[...] can be accumulated, converted into one another, passed on from generation to generation, but always dependent on the social contexts that condition its social 'value' and correspond to a symbolic power. This is because it is possible to visualize power everywhere, even if it is not totally visible and therefore often considered as an invisible power (Bourdieu, 1989, 1991).

Based on Bourdieu (1997a), social choices are never neutral; they are always inscribed in a game of domination. In view of this, it is understood, on the basis of what Munro (1993) and Cooper and Hopper (2006) have said that power in accounting is used to legitimize processes, so that the interests of actors who use accounting are not neutral. Thus, it is appropriate to use the theory of power relations proposed by Bourdieu to explain events in the accounting area. In addition to the above, Whittle and Mueller (2010) add that accounting can play a key role in power struggles, especially by presenting figures that represent a socially accepted truth about the value of activities.

Thus, accounting is a tool to rationalize the irrational and strengthen power relations (Bryer, 2011). Kuruppu et al. (2016) consider that power and domination are inherent to the social and that it is common for the agents involved in building strategies in a given field to strive to dominate, even if they have to counteract the others involved. In this way, one can perceive accounting as useful to promote bets and strategies, while trying to silence others, producing a symbolic violence (Farjaudon \& Morales, 2013). This symbolic violence is, for Bourdieu (2001), characterized by attitudes such as irony, rudeness, inhibition of speech, doubting the capacity of others, appropriation of ideas without giving credit, among others, which, according to Valle (2008), confer a hypnotic power to threats, bullying, demonstrations, orders or even calls to order.

In short, and to better elucidate the concepts, if Bourdieu's triad were applied in this research, the field would correspond to Brazilian research in the accounting area whose theoretical basis is based on Bourdieu, the habitus concerns the experiences, rules, practical knowledge of the authors (Bourdieu, 1989, 1997a, 2004a) in the accounting area and on Bourdieu's theory. As for capital, some of the capitals related to the countryside could be educational, social, economic, and symbolic (Bourdieu, 1991; Lebaron, 2017; Nogueira, 2017). Faced with such a complex issue, as well as with concepts and terminologies different from those one is used to in accounting, one understands how important is the care one should take when using them in research, so as not to distort what the other author wanted to convey. 


\section{EPISTEMOLOGICAL SURVEILLANCE}

When analyzing the national researches that used Bourdieu in the accounting area, it can be noted that the studies developed so far have been conducted from different perspectives. Among the articles recovered, the oldest is Riccio, Mendonça and Sakata (2007). In it, the authors use Pierre Bourdieu's conceptual model on knowledge fields to analyze the nature of Foucault's insertion in accounting thought, by surveying and systematizing articles published in international scientific accounting journals. In the study, the fields of knowledge are equivalent to Bourdieu's scientific field. The authors explain that the field of accounting knowledge, characterized as a space of domination and conflicts, is a place where agents seek prestige and recognition.

The study by Riccio et al. (2007), although presenting the relationship between the scientific field and the search for prestige and recognition, offers little discussion about the former and fails to highlight the aspects of symbolic capital, which the agent possesses or seeks to accumulate over time. Riccio et al. (2007) present the cultural and symbolic capital but relating them to the field. It should always be considered that there are readers who do not know a certain author and work to which the researcher refers in his research, which makes it difficult, in some cases, to understand, being necessary, therefore, a greater detail of some questions, even if, for the researcher, they seem logical and simple. An example of this is when Riccio et al. (2007) deal with "symbols" of Bourdieu: the ideal would be that there would be an explanation about what these symbols are and their relation with the work.

In this case, a study could be carried out analyzing how researchers in the accounting area perceive the scientific field, taking into consideration recognition, prestige, honor (definitions that correspond to symbolic capital). Another possibility would be to research which capital(s) are the ones that satisfy the researchers in the accounting area and make them remain active. One could also analyze how the "race" for the best CV Lattes occurs among researchers in the accounting area, considering in this case the scientific field and the social, educational, and symbolic capital.

Other studies have also turned to the scientific field in the accounting area: Araújo, Brito, Ribeiro and Lopes (2016) and Homero (2017). Araújo et al. (2016) aimed to understand how the scientific academy understands and uses the management report; thus, they deal with the scientific and business field. Already at the beginning of the theoretical reference, the authors make it clear that they approach the field as a set formed by relationship networks usually integrated and intertwined and not as an arena of power and conflict, according to Bourdieu. Furthermore, Araújo et al. (2016) emphasize that Bourdieu was not the reference of support of the work; they consider more significant the studies of DiMaggio and Powell $(1991,2004)$ and the interpretations of Machado-da-Silva, Guarido and Rossoni (2010). Araújo et al. (2016), emphasized the choice of authors to support the work. This is interesting and positive for two aspects: i) it shows that they have an understanding of the concept of the field, studied it and chose the concept and author(s) they consider most appropriate for the context analyzed; ii) they clearly position and expose the theoretical choices that guide the study. However, as a suggestion for future studies, a similar study could be undertaken, but analyzing, through discourse analysis, the symbolic power behind management reporting and even sustainability and annual reporting.

Observing the constitution of the scientific field and the low diversity of Brazilian accounting research to explain the absence of a consolidated line of interpretative and critical accounting research in Brazil, Homero (2017) highlights that the little diversity observed in Brazilian accounting research is a consequence of the low autonomy of the scientific field in relation to the professional field. In addition, he argues that the outstanding positions in academia over the years have been held by individuals also working in the professional field. Another point verified by the author for the lack of autonomy was the prevalence of studies in the accounting area with a positivist approach and, consequently, the power exercised by the editorial bodies of the most prominent journals. The author warns about the need to expand the thematic, methodological, and epistemological variety and for the approximation between the academy and the accounting practice.

In view of the concerns and worries exposed in Homero's (2017) article about the scientific field in accounting, it is possible to use Bourdieu's (2004b) work The Social Uses of Science, in search of explanations for this situation, considering that the scientific field is different from the others, which provides, according to the author, more failures than successes and therefore requires much creativity, innovation and will. According to Bourdieu (1989), it is necessary to break with empirical passivity 
and ratify the pre-constructions of common sense, making a difference in the academic world and, with this, enabling the evolution of scientific knowledge. If this really happens, there will be or it will be possible to start a true scientific revolution in all fields, including accounting. Consequently, more research and researchers would be recognized.

Moreover, complementing and seeking answers to Homero's (2017) concern with the scientific field in accounting, here again support is sought in Bourdieu (1989), that is, in his elucidation that the immigration of ideas is rarely done without harm, since they are defined consciously or unconsciously. In this case, it is understood that all effort is and will always be valid, even if it is not recognized as it should be. To this end, we can understand that, according to Bourdieu (2004b), the scientific field is broad, in which there are researchers who, in developing their research, encounter various obstacles, whether they come from the very institution in which they are inserted, from political powers present in this environment, or even due to the position they occupy in this field, as well as the fierce competition. In addition, agents occupy positions that demonstrate autonomy. It is understandable that a greater demand for the new would be interesting, for innovative and differentiated research in the accounting area.

Malsch, Gendron and Grazzini (2011) point out that not venturing into problems other than traditional and common ones can restrict the development of innovative ideas. In view of the above, future research could resume Homero's (2017) study and advance in the scientific field related to social capital, analyzing how social relations, established through co-authorships with researchers from other Brazilian universities and even from other countries, happen in the accounting area and whether they are converted into symbolic capital, for example: the publication in top journals.

In the same perspective, Frezatti, Nascimento and Junqueira (2009) discuss the scarcity of national and international vehicles recognized for publication in Managerial Accounting. The authors stress that, although there are publications in this area in North American journals, the participation is small in comparison with other areas of accounting and even smaller when it comes to non-American authors. To explain this fact, they resort to a citation from Bourdieu (1992), in which he describes that the mechanisms of social reproduction aim at legitimizing what is considered 'the correct'. In the direction of research by Frezatti et al. (2009), new studies could advance by exploring the question of habitus, i.e., the practical knowledge and previous experiences that are linked to this context and that make it difficult to insert new studies and different authors in the field. Moreover, the issue of scientific capital can be a useful approach to explain the publications of a certain 'elite'.

In the study on international consulting in expansion and emerging forms of globalization of exchanges and managerial litigation, Donadone (2010) stresses that the format of the clashes between consultants and managers is driven by the positioning of agents in their respective fields, with mitigation in the differentiation between consultants and managers in similar positions. The clashes become naturalized with the dominant position, in which managers attribute to the performance of consultants the model of conduct to be followed, which can be considered a process of symbolic violence, in the context of this concept advocated by Bourdieu (2000).

Based on the above, the study by Donadone (2010) could have offered a more detailed discussion on symbolic violence, describing, for example, how the naturalization of dominant position occurs. It is relevant to note that, according to Mauger (2017), naturalization of dominance occurs through speech, gestures, things, and events. In any case, new studies could explore symbolic violence in the scientific field of accounting from various perspectives. For example, as symbolic violence occurs in the coordination-pupil-teacher relationship, in the teacher-student relationship, counselor-guide relationship, and even in the relationship between classmates, or in other fields, such as family businesses, public or class institutions.

Miranda, Casa Nova and Cornacchione (2012) used two works by Bourdieu to support the concept of reference regarding the professional/teacher when evaluating the predominant knowledge of the teachers perceived as reference professors in the Graduate course in Accounting Sciences of a Brazilian public university. For the authors, the term reference refers to the teachers who stand out positively before the students. As a way to move forward in this discussion, new research may identify teachers-referenced in the post-graduation course in Accounting, in order to question how they feel; which capitals they mobilize; how the agents who circulate in the fields in common perceive them; how habitus and capitals are used in this context.

In the business context, in order to analyze the effect of the capital stock of the Board of Directors (board) on the market value of companies listed on BM\&F Bovespa, Aranha, Rossoni and Mendes-da-Silva (2016) adopt as an indicator of capital stock the relational resources present in the direct, indirect and heterogeneous bonds of the board. Thus, the authors used the 
volume of social capital, measured by the size of the network and the volume of capital (economic, cultural, and symbolic), and held by the individual connected to the network. However, the study does not describe exactly what the other capitals are and how they were considered by them. Another relevant point is the fact that the authors have adopted Lin, Cook and Burt's (2001) more contemporary work to conceptualize social capital as a reference. Bourdieu is presented as a secondary author to support some concepts in the theoretical framework. In view of this, future studies may broaden the findings of Aranha et al. (2016) by observing the social capital present in the board interlocking, i.e., the collaborative networks, social ties present among board members, through Bourdieu's theoretical lens.

Other authors who adopted the concept of capital were Mizumoto, Artes, Lazzarini, Hashimoto and Bedê (2010), when they empirically examined the impact of three factors that can prolong the survival of nascent firms: the human capital of the entrepreneur, his social capital and the adoption of managerial practices after the opening of the new firm. They emphasize that the discussions on the importance of social capital have been driven by the efforts of sociologists such as Bourdieu (1986) and Coleman (1988), since these authors have emphasized the benefits that actors can obtain through their insertion in social networks. New studies could use the two classical authors, comparing the empirical results from two perspectives, already making clear since the beginning of the work that the authors' concept of social capital differs. Moreover, little is known about whether and how capital is mobilized to prolong and protect enterprises in different life cycles: birth, growth, maturity, rebirth, and decline.

Barbosa, Higgins, Cunha and Ribeiro (2016), when analyzing the networks of academic co-authorship of Brazil's accounting science programs, also considered the concept of 'social capital' of Bourdieu (1980) and Coleman (1988, 1992, 1994), exposing that this capital is the main sociological export product in the last thirty years. The authors complement that the social representation of Coleman and Bourdieu remained for many years at the level of an ambiguous notion, between commonplace and analogy. In the study, the authors opportunely emphasize that each of the classics seeks to clarify different problems and both have contributed decisively to the scientific diffusion of this concept.

Based on the study by Barbosa et al. (2016), a gap could be filled by means of future studies, in order to empirically analyze how capital is fed backwards, considering that it is accumulated and can be converted into each other, contributing to the reproduction of social domination, since the more capital the agent has, the more he will be able to dominate by the power he will possess and, consequently, reproduce this power. Besides, other forms of capital could be considered, such as the economic, educational, and political capital, among others that may emerge in the field being investigated.

Finally, in the study by Tana, Mesquita, Gonçalves and Martins (2017), the concept of social capital is also used, however, besides Bourdieu's $(1998,2006)$ and Coleman's $(1988,1994)$ approach, it is differentiated by rescuing the concepts of social capital exposed by Burt $(1992,2000)$ to evaluate the influence of social networks on the management capacities of cooperatives that operate in the dairy sector. In the research, the authors presented a construct with variables that concern the relationship with communities, involving the recognition given to the cooperative by the affected communities. In the context observed, they conclude that the partnership can be considered as social capital. Due to the different approaches presented to measure social capital, Tana et al. (2017) highlighted that the difficulty of measuring the benefits of the network is also presented by Burt, Bourdieu, and other authors.

To this end, in the context of cooperatives, studies similar to that of Tana et al. (2017) can advance by taking into account habitus, i.e. previous experiences, knowledge, rules and beliefs and, in addition, discuss the recognition and benefits resulting from this social capital through symbolic capital. It would also be interesting to compare the results of different types of cooperatives (e.g. agriculture, production, credit, among others).

Another question observed in the study by Tana et al. (2017) is that, for Bourdieu (2006) ${ }^{1}$, social capital is a sum of resources, real or virtual. However, when consulting Bourdieu's work, it can be seen that the author considers that social capital refers to the relationship with people, that is, to social ties and not exactly as the sum of real or virtual 'resources' (Bourdieu, 2005).

In view of the above and without the pretension of covering the totality of possibilities, it is possible to realize how rich and current Bourdieu's work is and the countless opportunities for new research. However, it is essential to be careful with

${ }^{1}$ We are looking for the work of Bourdieu (2006) cited and this is from 2005 and not 2006. 
the use of words, with their meanings. This is the vigilance that Bourdieu so much advocates, especially in the context of qualitative and critical research, because, in this case, words have greater power. Moreover, in the words of Wacquant and Akçaoğlu (2018, p. 148), "To grasp the distinctive mental modus operandi of any great thinker - be it Bourdieu, Hannah Arendt or IbnKhaldun - you must become deeply entangled in your intellectual web," and, further, "[...] The goal is not to convert the student (social theory is not theology), but to make him/her familiar with a particular way of thinking, which you can appropriate and adapt to your own analytical needs in the future". It follows that it is possible to revisit Bourdieu's work for the accounting field, and especially for the Brazilian accounting field, however, it is necessary to be vigilant and, above all, to have a deep understanding of the primary concepts of his work, contextualized in its time, space and field.

\section{“EATING BY THE EDGES”}

Based on the analysis of the abstracts and keywords of the studies recovered in the process of a search in national journals and considering only those used for this study (those presented in the previous section), which presented concepts and/or arguments supported by Bourdieu's theory, a word cloud was elaborated, as can be seen in Figure 1 .

Figure 1

Word cloud

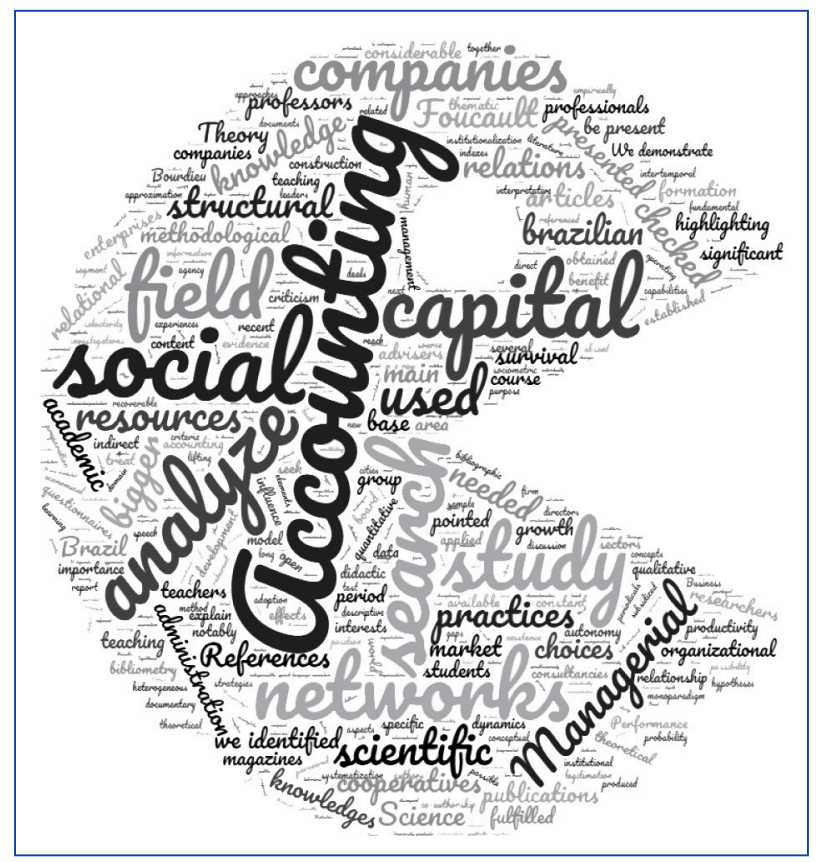

Source: Research data.

You can see the highlight of the word accounting, which is relevant because of the selection of articles. In addition, the words capital, research, networks, field, study, and analysis are in evidence, as well as social and managerial, and are more present than the other words in the summaries analyzed. In view of the above, it is possible to notice that the themes that stood out are related to networks, social relations, that is, to social capital. The word capital is in evidence, as the studies of Frezatti et al. (2009), Mizumoto et al. (2010), Barbosa et al. (2016), Aranha et al. (2016) and Tana et al. (2017) deal with the capital stock, and the main theme has always been related to accounting, i.e., the countryside.

Another word in evidence is field, since more than half of the studies analyzed in this essay investigated the scientific field: Riccio et al. (2007), Miranda et al. (2012), Araújo et al. (2016) and Homero (2017). Research and studies are also words in evidence in Figure 1, precisely because of the predominance of the look at the scientific field, the field of researchers and other professionals who in some way have a direct relationship with this field. 
The studies analyzed in the managerial area that used some of Bourdieu's terms were those of Frezatti et al. (2009), Donadone (2010) and Mizumoto et al. The first discusses the issue of networks, i.e., social capital. Donadone (2010) analyzed the theme of symbolic violence within this area and, finally, Mizumoto et al. (2010) also studied social capital based on Bourdieu and other authors.

It is noteworthy that even if the author Foucault does not stand out in the cloud of words, he is present. However, we note that the name Bourdieu, which is the focus of this study, is also not easily identified. This stems from the fact that most abstracts do not explain the author. When resuming the abstracts, it was possible to see that the study of Riccio et al. (2007) uses Pierre Bourdieu's conceptual model on fields of knowledge to analyze the nature of Foucault's insertion in accounting thought. It was found that the authors emphasized and cited Foucault several times in their summary, a fact that led the author to stand out in the cloud of words.

Thus, it was observed that only the studies of Riccio et al. (2007) and Homero (2017) presented the name of Bourdieu as the basis of research in their abstracts, citing him only once and both dealing with the scientific field. This fact may be due to the authors' fear of putting in evidence a sociologist little diffused in the field of accounting research. It may be opportune to observe that, by searching the Scopus Portal, in journals related to accounting, organizations and business, it is possible to recover around 50 works whose Bourdieusian theme is related to accounting. The first was in 1995, published by Lee and entitled "Shaping the US academic accounting research profession: The American accounting association and the social construction of professional elite". From that year until 2015, we observed a publication that was not very expressive (between one and four articles per year, with the exception of 2011), a fact that takes on another dimension from 2016, indicating that Bourdieu 'was discovered' by accounting research published in English.

\section{CRITICAL REFLECTIONS}

Recognizing that research based on Bourdieu's theory is present in the field of accounting, although this is happening little by little, is important. Admitting that there are limitations and resistance in the field in relation to research that moves away from the mainstream is necessary. However, a relevant point is the fact that these researches are consolidating their space and inserting themselves in accounting journals. We note that Bourdieu's work is gradually entering the field of accounting research, which seems to us to be a process that will still yield good results, given the multiple possibilities that the vast work of this sociologist has to offer to studies dedicated to observing agents, capitals, fields, habitus, body hexis, and symbolic violence.

We understand that most of the analyzed works tend to concentrate attention on the study of social capital, which is incipient in relation to the amplitude of the theory, as well as Bourdieu's triad of power relations - here it is considered that the challenge is to cover the triad in the restricted space of the periodicals. Townley (2014) points out that, in general, few studies have combined the analysis of the triad fields, habitus and capital, the majority having used only one element. The same occurs in the accounting area, in which Bourdieu's theory has not yet been significantly explored (Malsch et al., 2011).

However, Townley (2014) considers that all three elements (fields, habitus, and capital) exist in a theoretical way to understand practices, regardless of the area investigated. Malsch et al. (2011) point out that even using only one of Bourdieu's concepts in a fragmented way, such studies should not be underestimated, but one should consider that it may be difficult or impossible to perceive the benefits of Bourdieu's structure. In the light of the above, Malsch et al. (2011, p. 194-220) continue: "Does it make sense to use certain concepts extracted from a comprehensive system of thought in a fragmented way?"; "[...] why Bourdieu is seldom fully mobilized in the accounting literature?"

When Bourdieu (1989, p. 32) points out that "[...] to break with empirical passivity, which does nothing but ratify the preconstructions of common sense" - a procedure over which he has remained vigilant in all his work - some questions arise for reflection: why is it so difficult to break, to break paradigms? To raise new questions and propose new methods, brilliant ideas that no one has ever dared to expose before? Are we not just being mere spectators, producing more of the same? As difficult as it may be, who knows this is the necessary exercise, capable of making a difference in academia, enabling the evolution of scientific knowledge? 
From the moment researchers dare to leave the 'comfort zone' and think 'outside the box', Bourdieu (1989) stresses that there will be a change, whether significant or not, but it will be a road with no return. Thus, one must know how to look, agree, disagree, and criticize when it is necessary, because disagreeing and criticizing are important for evolution.

In all cases, when analyzing the evolution of accounting research based on the Bourdieusian approach, it is perceived and believed that, little by little and over the years, it is consolidating and being deepened. New researchers contribute with the current ones in the search for their space. It is worth mentioning that the choice of the popular expression 'eating by the edges' intends to portray the reality of accounting research using Bourdieu, since it has been gradually inserted in events and journals in the area without attracting much attention, until it becomes something widely accepted by 'peers'.

"Eating by the edges" also refers to the sense of the relationship with the elements that are being analyzed, these being the same in most studies that is, basically the scientific field and social capital, although some studies have been observed that focus on the managerial area - among which one of these took into consideration the notion of symbolic violence. Another important point is the use, by some studies, of Bourdieu's theory to explain the social capital, jointly with authors such as Lin, Burt and Coleman. This can be enriching, if there is epistemological vigilance and adequate appropriation of knowledge about how the concepts of social capital, present in the work of different authors, are imbricated and in which aspects they are opposed. It is necessary to point out that, although some researches mention economic capital, symbolic capital, cultural capital and habitus, the discussions remain withdrawn when the set of works proposed by Bourdieu offers countless possibilities.

Given the above, if so, many facts can be observed by Bourdieu's theoretical lens in accounting, the question is: why is there still so much resistance to acceptance? Is this resistance a reflection of the little attention paid by graduate programs to sociology? It would be interesting to have a reflection on this, so that there would be more interdisciplinarity. The fact that theories from other areas are not explored can be explained, at least in part, by the concern about the acceptance of research. Moreover, in the case of Bourdieu, even if he is a renowned author in the multidisciplinary and international context, especially in education, it is necessary to be careful when using his theory to underpin and sustain certain issues, as there is a risk of forcing explanations that are not possible.

It is necessary to take up again and remember that allodoxia must always be taken into consideration, because some concepts depend on the reality and context analyzed to be used, and thus evaluate and judge when it is appropriate or not essential. An example is the use of the concept of cultural capital which, for Bourdieu $(1991,2004 a)$, can be represented, for example, by visits to museums, works of art. This, however, does not match the Brazilian reality, since the country's culture related to works of art and museums is very different from that existing in France, the country of the sociologist, in which the concept was developed. Thus, the words of Wacquant and Akçaoğlu (2018, p. 152) are relevant in stating that "The Turkish Bourdieu is not the Brazilian Bourdieu, which is not the Norwegian Bourdieu or the French Bourdieu". Therefore, however difficult it may be to interpret certain concepts, it is possible to understand that, when used, it is indispensable for the author to express and transmit what a certain "key concept" of his work means.

Everything presented here is in line with what Bourdieu (1989, p. 45) stressed, in his work The Symbolic Power, about the fact that the problem is that we only "reproduce the doxa received from the ancestors", being indispensable a rupture through the conversion of the gaze, of a new look, of 'producing' a new man, being necessary a mental revolution, involving the change of the whole social world vision. For this, if not by breaking paradigms, how will we produce this new man and a new look?

\section{ACKNOWLEDGMENTS}

In accordance with Ordinance No. 206 of September 4, 2018, the present work was carried out with the support of the Coordenação de Aperfeiçoamento de Pessoal de Nível Superior - Brazil (CAPES Foundation) - Financing Code 001. 


\section{REFERENCES}

Aranha, C. E., Rossoni, L., \& Mendes-da-Silva, W. (2016). Capital social do Conselho de administração e desempenho de empresas de capital aberto brasileiras. Revista de Administração Mackenzie, 17(1), 15-39.

Araújo, U. P., Brito, M. J., Ribeiro, L. M. P., \& Lopes, F. T. (2016). Meta interpretação: quinze anos de pesquisa com o Relatório da Administração. Revista Contabilidade \& Finanças, 27(71), 217-231.

Barbosa, J. E., Neto., Higgins, S. S. S., Cunha, J. V. A., \& Ribeiro, A. C. (2016). Capital social e seletividade em redes de coautoria acadêmica: o caso das ciências contábeis no Brasil. Brazilian Business Review, 13(6), 239-269.

Baxter, J., \& Chua, W. F. (2008). Be(com)ing the chief financial officer of an organization: Experimenting with Bourdieu's practice theory. Management Accounting Research, 19(3), 212-230.

Bourdieu, P. (1980). Le capital social: notes provisoires. Actes de la Recherche en Sciences Sociales, 31(31), 2-3.

Bourdieu, P. (1986). The forms of capital. In: J. G. Richardson (Ed.), Handbook of theory and research for the sociology of education (pp. 111-113). Westport, CO: Greenwood Press.

Bourdieu, P. (1989). O poder simbólico (4a ed.). Rio de Janeiro, RJ: Bertrand Brasil.

Bourdieu, P. (1991). Language and Symbolic Power. Cambridge, MA: Harvard University Press.

Bourdieu, P. (1992). O poder simbólico. Rio de Janeiro, RJ: Bertrand Brasil.

Bourdieu, P. (1997a). A dominação. Mont-Saint-Aignan, France: Universidade de Rouen.

Bourdieu, P. (1997b). Passport to duke. Metaphilosophy, 28(4), 449-455.

Bourdieu, P. (1998). O capital social - notas provisórias. In M. A. Nogueira, \& A. Catani (Eds.), Escritos de educação (pp. 65-70). Petrópolis, RJ: Vozes.

Bourdieu, P. (2000). Les structures sociales de l'économie. Paris, France: Éditions du Seuil.

Bourdieu, P. (2001). Meditações pascalianas. Rio de Janeiro, RJ: Bertrand Brasil.

Bourdieu, P. (2004a). Coisas Ditas. São Paulo, SP: Brasiliense.

Bourdieu, P. (2004b). Os usos sociais da ciência: por uma sociologia clínica do campocientífico. São Paulo, SP: Unesp.

Bourdieu, P. (2005). The social structures of the economy. Cambridge, UK: Polity Press.

Bourdieu, P., Chamboredon, J. C., \& Passeron, J. C. (2015). Ofício de sociólogo: metodologia da pesquisa na sociologia (8a ed.). Petrópolis, RJ: Vozes, 2015

Bourdieu, P., \& Wacquant, L. J. D. (1992). An invitation to reflexive sociology. Chicago, IL: University of Chicago Press.

Bryer, A. R. (2011). Accounting as learnt social practice: The case of the empresas recuperadas in Argentina. Accounting, Organizations and Society, 36(8), 478-493.
Burt, R. S. (1992). The social structure of competition. In N. Nohria, \& R. G. Eccles (Eds.), Networks and organizations: structure, form, and action (pp. 401-411). Boston, MA: Harvard Business School Press.

Burt, R. S. (2000). The new structure of social capital. Research in Organizational Behavior, 22, 345-423.

Coleman, J. S. (1988). Social capital in the creation of human capital. American Journal of Sociology, 94, 95-120.

Coleman, J. S. (1994). Foundations of social theory. Cambridge, MA: Harvard University Press.

Coleman, J. S. (1992). The rational reconstruction of society. Presidential Address. American Sociological Review, 58, 1-15.

Cooper, D. J., \& Hopper, T. (2006). Critical theorising in management accounting research. Handbooks of Management Accounting Research, 1, 207-245.

Dimaggio, P. J., \& Powell, W. W. (1991). The new institutionalism in organizational analysis. Chicago, IL: University of Chicago.

Dimaggio, P. J., \& Powell, W. W. (2004). The iron cage revisited. In: F. Dobbin (Ed.), The new economic sociology (pp. 111-134). Princeton, NJ: Princeton University.

Donadone, J. C. (2010). Consultoria internacional em expansão e formas emergentes de globalização das trocas e contenciosos gerenciais. Tempo social, 22(1), 101-125.

Farjaudon, A. L., \& Morales, J. (2013). In search of consensus: The role of accounting in the definition and reproduction of dominant interests. Critical Perspectives on Accounting, 24(2), 154-171.

Frezatti, F., Nascimento, A. R., \& Junqueira, E. (2009). Desenvolvimento da pesquisa em Contabilidade Gerencial: as restrições da abordagem monoparadigmática de Zimmerman. Revista Contabilidade \& Finanças, 20(49), 6-24

Hey, A. P. (2017). Dominação. In A. M. Catani, M. A. Nogueira, A. P. Hey, \& C. Medeiros (Orgs.), Vocabulário Bourdieu. Belo Horizonte, MG: Autêntica Editora.

Homero, P. F., Jr. (2017). A constituição do campo científico e a baixa diversidade da pesquisa contábil brasileira. Revista de Educação e Pesquisa em Contabilidade, 11(3), 314-328.

Hoskin, K. W., \& Macve, R. H. (1986). Accounting and the examination: a genealogy of disciplinary power. Accounting, Organizations and Society, 11(2), 105-136.

Kuruppu, C., Adhikari, P., Gunarathna, V., Ambalangodage, D., Perera, P., \& Karunarathna, C. (2016, December). Participatory budgeting in a Sri Lankan urban council: A practice of power and domination. Critical Perspectives on Accounting, 41, 1-17.

Lahire, B. (2017). Campo. In A. M. Catani, M. A. Nogueira, A. P. Hey, \& C. Medeiros (Orgs.), Vocabulário Bourdieu (pp. 64-66). Belo Horizonte, MG: Autêntica Editora.

Lebaron, F. (2017). Capital. In A. M. Catani, M. A. Nogueira, A. P. Hey, \& C. Medeiros (Orgs.), Vocabulário Bourdieu (pp. 101-102). Belo Horizonte, MG: Autêntica Editora. 
Lin, N., Cook, K. S., \& Burt, R. S. (2001). Social capital: Theory and research. New Jersey, NJ: Transaction Publishers.

Machado-da-Silva, C. L., Guarido, E. R., Filho, \& Rossoni, L. (2010). Campos organizacionais: seis diferentes leituras e a perspectiva de estruturação. RAC-Revista de Administração Contemporânea, 14(esp.), 109-147.

Malsch, B., Gendron, Y., \& Grazzini, F. (2011). Investigating interdisciplinary translations: The influence of Pierre Bourdieu on accounting literature. Accounting, Auditing \& Accountability Journal, 24(2), 194-228.

Mauger, G. (2017). Violência Simbólica. In A. M. Catani, M. A. Nogueira, A. P. Hey, \& C. Medeiros (Orgs.), Vocabulário Bourdieu (pp. 359-361). Belo Horizonte, MG: Autêntica Editora.

Meneghetti, F. K. (2011). O que é um ensaio-teórico? Revista de Administração Contemporânea, 15(2), 320-332.

Miranda, G. J., Casa Nova, S. P. C., \& Cornacchione, E. B., Jr. (2012). Os saberes dos professores-referência no ensino de contabilidade. Revista Contabilidade \& Finanças, 23(59), 142-153.

Mizumoto, F. M., Artes, R., Lazzarini, S. G., Hashimoto, M., \& Bedê, M. A. (2010). A sobrevivência de empresas nascentes no estado de São Paulo: um estudo sobre capital humano, capital social e práticas gerenciais. Revista de Administração, 45(4), 343-355.

Munro, R. (1993). Just when you thought it safe to enter the water: Accountability, language games and multiple control technologies. Accounting, Management and Information Technologies, 3(4), 249-271.
Nogueira, M. A. (2017). Capital cultural. In A. M. Catani, M. A. Nogueira, A. P. Hey, \& C. Medeiros (Orgs.), Vocabulário Bourdieu (pp. 103-106). Belo Horizonte, MG: Autêntica Editora.

Riccio, E. L., Mendonça, O. R., Neto, \& Sakata, M. C. G. (2007). Movimentos de teorias em campos interdisciplinares: a inserção de Michel Foucault na contabilidade. Revista de Administração Contemporânea, 11(2), 11-32.

Setton, M. G. J. (2002). A teoria do habitus em Pierre Bourdieu: uma leitura contemporânea. Revista Brasileira de Educação, 20, 60-70.

Tana, W., Mesquita, J. M. C., Gonçalves, C. A., \& Martins, H. C. (2017). Redes Sociais, Capital social e Desempenho: Estudo com Cooperativas Brasileiras do Segmento Lácteo. Revista de Ciências da Administração, 19(48), 38-53.

Townley, B. (2014). Bourdieu and Organizational Theory: A Ghostly Aparition? In P. Adler, P. Du Gay, G. Morgan, \& M. Reed (Eds.), The Oxford Handbook of Sociology, Social Theory, and Organization Studies: Contemporary Currents (pp. 39-63). Oxford, UK: Oxford University Press.

Valle, I. R. (2008). Pierre Bourdieu: A pesquisa e o pesquisador. In L. Bianchetti, \& P. Meksenas (Org.), A trama do conhecimento. Teoria, método e escrita em ciência e pesquisa (pp. 95-117). Campinas, SP: Papirus.

Wacquant, L., \& Akçaoglu, A. (2018). Prática e poder simbólico em Bourdieu: a visão de Berkeley. BIB, 85(1), 148-163.

Whittle, A., \& Mueller, F. (2010). Strategy, enrolment and accounting: the politics of strategic ideas. Accounting, Auditing \& Accountability Journal, 23(5), 626-646.

Mara Vogt

ORCID: https://orcid.org/0000-0002-3951-4637

Ph.D. in Accounting and Administration from the Regional University of Blumenau (FURB); Professor of Undergraduate Accounting and Administration courses at the Federal University of Santa Catarina (UFSC). E-mail: maravogtcco@gmail.com

Marcia Zanievicz da Silva

ORCID: https://orcid.org/0000-0003-1229-7705

Ph.D. in Accounting and Administration from the Graduate Program in Accounting Sciences of the Universidade Regional de Blumenau (PPGCC/FURB); Professor of the Graduate Program in Accounting and Administration of the Universidade Regional de Blumenau (FURB). E-mail: marciaza@gmail.com

Ione Ribeiro Valle

ORCID: https://orcid.org/0000-0001-7496-3959

Ph.D. in Education Sciences from Université René Descartes- Paris V Sorbonne; Professor of the Graduate Program in Education at Universidade Federal de Santa Catarina (UFSC). E-mail: ione.valle@ufsc.br 